\title{
EVOLUTIONARY THEOLOGY: A NEW CHAPTER IN THE RELATIONS BETWEEN THEOLOGY AND SCIENCE
}

\begin{abstract}
Despite many arduous attempts to reconcile the separation between theology and science, the common ground where these two areas of intellectual inquiry could converge has not been fully identified yet. The purpose of this paper is to use evolutionary theology as the new and unique framework in which science and theology are indeed brought into coherent alignment. The major step in this effort is to acknowledge that theology can no longer dialogue with science but must assume science and its method as its conceptual foundation. This approach successfully does away with any tensions that may arise between the two disciplines and establishes a firm ground on which neither of them will turn into ideology. Moreover, it enables the dialogue with contemporary scientific atheism on solid grounds and the restoration of the credibility of theology in the secularist culture of the day.
\end{abstract}

Keywords: evolution; hermeneutics; rationality; picture of the world; relations between science and theology

1. Introduction. 2. The synthesis of Aquinas. 3. Ways of relating science and religion. 4 . What is evolutionary theology? 5. Methodological issues. 6. Reshaping the integration. 7. Conclusions.

\section{INTRODUCTION}

It is beyond doubt that religion is older than science. The relations between science and religion date back to very birth of science, that is, to the turn from the 7th to the 6th century $\mathrm{BC}$ when representatives of the Ionian school of philosophy launched an enduring process of demythologization of nature. ${ }^{1}$ Their strong belief in the power of the human mind to unveil nature's workings resulted in a progressive

1 O. Pedersen, The Two Books: Historical Notes on Some Interactions Between Natural Science and Theology, Vatican Observatory Foundation, Vatican 2007, 4-7. 
depopulation of the pantheon of gods that eventually gave rise to one of the most fundamental principles of science: methodological naturalism. In short, nature can be only explained by nature.

It took about two thousand years of considerable intellectual effort to integrate science and religion into a contrapuntal relationship, achieved in medieval thought especially through the works of St. Thomas Aquinas. ${ }^{2}$ Unfortunately, the condemnations of 1277 by the bishop of Paris, Etienne Tempier, led philosophers to a growing distrust of theologians. As a result, philosophy slowly begun to disengage from theological inquiry and develop without reference to religion as its motivating factor. ${ }^{3}$ This separation dominated modern times and hasn't been restored until the present day.

Although commonly used in most of the systematic studies on the subject, the expression 'relations of science and religion' means rather 'relations of science and theology'. It is not difficult to see that such relations do not concern religion as a whole, which comprises not only the doctrine but the rituals, morality and institutions for its promotion and teaching as well. As for doctrinal issues, which play a key role in both science and theology, the pursuit of truth is their main objective. In other words, it is the interaction between the scientific and theological discourse that is considered here.

The goal of this paper is to offer some preliminary considerations on how science and theology can be brought back into a fruitful synthesis within a new theological paradigm known as evolutionary theology, thereby giving rise to a new chapter in their relations. The synthesis proposed respects the distinct objects of inquiry of science and religion. At the same time, it eliminates potential areas of conflict. The goal will be pursued in the following order. Firstly,

2 E.g. J. Pieper, Scholasticism: Personalities and Problems of Medieval Philosophy, St. Augustine Press, South Bend 2001.

3 J. Mączka, Średniowieczny konflikt nauki z teologia (potępienie z 1277 r.), in: M. Heller, Z. Liana, J. Mączka, W. Skoczny, Nauki przyrodnicze a teologia: konflikt i współistnienie, OBI - Biblos, Kraków - Tarnów 2001, 115-126. 
the specificity of the Thomistic synthesis of faith and reason will be presented to provide a suitable background for further analysis. Secondly, the existing typologies concerning the relations of science and religion will be briefly discussed to identify a most suitable type or, rather, a model which will be used in this study to characterize evolutionary theology. Thirdly, the modern understanding of the nature of theological language will be surveyed to establish its dependence on the important hermeneutical category of the picture of the world. Updating the image of the world with the latest scientific developments will allow us to justify the reinterpretation of the theological doctrine. Lastly, it will become evident that evolutionary theology integrates science and religion in a flexible way, so that any future adjustments of the image of the world will not disrupt the integrity of their synthesis and might lead to new theological insights. As a result, it will be suggested that the conflict between science and religion arises only when either of the two turns variables into absolutes.

\section{THE SYNTHESIS OF AQUINAS}

As mentioned above, the philosophy and theology of St. Thomas Aquinas are commonly considered to be the climax of medieval thought, for they achieve a unique synthesis of faith and reason. ${ }^{4}$ Replacing the prevalent Neo-Platonism with the philosophy of Aristotle as the conceptual foundation of theology was but an extremely courageous and ingenious move made by Aquinas, through which the metaphorical language of the former gave way to the conceptual clarity and precise logic of the latter. Following Aristotle, Aquinas claimed that knowledge of nature is attained through an

4 J. Pieper, Scholasticism: Personalities and Problems of Medieval Philosophy, op. cit.; John Paul II, Fides et Ratio, Vatican City State 1998, art. 43-44. 
intellectual grasp of the substance of things. ${ }^{5}$ The knowledge of the substance of things does not exceed the capacity of the human intellect, which has a limited understanding of the Divine substance. The intellect, however, arrives at the simplest truths that God exists and that His substance has certain attributes as the first principle. ${ }^{6}$ This is possible due to the likeness of things created to their Creator. Consequently, faith becomes the natural extension of reason in providing insight into the truths that lie beyond reason's natural powers. Although the knowledge of substances proceeds through their representations as common natures, ${ }^{7}$ the ontology of substance is assumed to underpin reality at its fundamental level. In short, it is the fundamental ontology.

It was only three years after Aquinas' death that the 1277 condemnations were announced by the bishop of Paris, Etienne Tempier, following the allegedly heterodox interpretations of the Aristotelian writings. The condemnations resulted in a profound separation of faith and reason. The contrapuntal relationship established by Aquinas quickly turned into a marked opposition manifesting itself in such classical episodes as the Galileo case or the Darwin case. The Darwin case continues to spark much controversy, bringing forth radically contrasting stances: (1) atheism: the claim that Darwinism has effectively explained religion away; ${ }^{8}$ and (2) biblical fundamentalism: the rejection of Darwinism on the grounds of its materialistic character and its obvious disagreement with a literal interpretation of the biblical account of creation. ${ }^{9}$ In addition to this,

5 St. Thomas Aquinas, Summa Contra Gentiles I, 3, 7.

6 St. Thomas Aquinas, Faith, Reason and Theology. Questions I-IV of his Commentary on the 'De Trinitate' of Boethius, Pontifical Institute of Medieval Studies, Toronto 1987.

7 E.g. J. Owens, Cognition: An Epistemological Inquiry, Center for Thomistic Studies, Houston 1992, 139-165.

8 E.g. R. Dawkins, The God Delusion, Bantam Books, New York 2006.

9 E.g. G.J. Keane, Creation Rediscovered: Evolution and The Importance of the Origins Debate, TAN Books and Publishers, Rockford 1999. 
there are more sophisticated strategies of denying Darwinism known under the general umbrella of intelligent design. ${ }^{10}$ Such situation is highly unsatisfactory from the epistemic point of view, for science yields knowledge on the work of the Divine creation and as such should not contradict revelation. Despite the numerous efforts to reconcile the two disciplines, there persists a belief that science and religion remain in conflict. Unfortunately, this belief may become even more ingrained as the current and rapid development of the cognitive sciences challenges some of the fundamental concepts of anthropology. ${ }^{11}$

\section{WAYS OF RELATING SCIENCE AND RELIGION}

The complexity of relations between science and religion following their breach is most fully captured in the typology proposed by Ian G. Barbour, ${ }^{12}$ who distinguishes four models of relations: conflict, independence, dialogue and integration. Another one formulated by Dominique Lambert names three such models: integration, separation and explication. ${ }^{13}$ Since Lambert's typology is a bit too broad and, most importantly, the model of integration implies dominance of religion over science, or vice versa, rather than a fruitful synthesis, the typology put forward by Barbour seems more appropriate for the purpose of this study.

According to Barbour's taxonomy, the conflict model assumes that religion and science are incompatible and that only one of them is a

10 E.g. M. Behe, Darwin's Black Box: The Biochemical Challenge to Evolution, The Free Press, New York 1996; W.A. Dembski, The Design Inference: Eliminating Chance Through Small Probabilities, Cambridge University Press, Cambridge 1995.

11 E.g. W.P. Grygiel, Konceptualne wyzwania nauk kognitywnych dla antropologii filozoficznej i teologicznej, in: Teologia fundamentalna wobec współczesnych wyzwań nauk o człowieku, ed. P. Artemiuk, Płocki Instytut Wydawniczy, Płock 2019, 120-143.

12 I.G. Barbour, When Science Meets Religion, Harper One, New York 2000.

13 D. Lambert, Sciences et théologie - Les figures d'un dialogue, Lessius, Bruxelles 1999. 
legitimate source of knowledge. This type of model is evident in the stance of scientific materialism, which regards religion as a delusion. The only true knowledge is scientific knowledge, which is subject to testing and objective analysis. The opposing stance, namely that of biblical literalism, considers the Bible as the only source of truth, and scientific knowledge must be interpreted according to what the Bible says. It remains beyond doubt that this model precludes any reconciliation between science and religion. A more in-depth analysis would easily reveal an array of unjustified premises entailed by this model entails, but this falls beyond the scope of this study.

As Barbour moves to the second type of relations between science and religion, namely that of independence, it becomes gradually obvious that with each next type he instills more optimism that a reconciliation is possible and, as it will eventually turn out, entirely natural. Independence avoids conflicts by allocating science and religion into separate compartments by articulating their radical differences in "the questions they ask, the domains to which they refer and the methods they employ." 14 In regard to the disjunction of domains, science is the study of objective facts, while the focus of religion is that of personal values. In other words, science deals with the "what" and religion deals with the "why." Thus, they cannot conflict because they have different functions.

The dialogue type is a further relaxation of independence in the direction of bringing science and religion together and making their interaction more constructive. While it holds that religion and science are mostly separate and lack conceptual unity, it admits that in some cases an explanation in one field will have implications for the other. As Barbour points out: "In comparing science and religion, dialogue emphasizes similarities in presuppositions, methods and concepts, whereas independence emphasizes the differences." ${ }^{15}$ For instance,

14 I.G. Barbour, When Science Meets Religion, op. cit., 17.

15 Ibid., 23. 
the apparent sharp cut between science and religion as disjunctively referring to the objective and subjective can be alleviated by stressing the impact of the creativity of the researcher's mind in the formulation of a scientific theory. This is best evidenced by Einstein's famous "free interplay of ideas." 16

The final type that Barbour describes is that of integration. On this view, both religion and science do have the authority to reveal the truth and, most importantly, the two perspectives are inextricably intertwined. One's theological perspective shapes how one uses and interprets science, but science also influences how we view God and his revelation and actions in the world. According to Barbour, this stance allows for a systematic synthesis in which science and religion contribute to a coherent worldview, thereby bringing the conflict between science and religion to a definite close. This synthesis calls for a new metaphysics that will constitute a shared conceptual scheme to warrant a space of common inquiry.

\section{WHAT IS EVOLUTIONARY THEOLOGY?}

Evolutionary theology is a novel paradigm that assumes as its conceptual foundation the evolutionary dynamic picture of the Universe, in which the history of humanity is deeply intertwined with the history of the Universe. According to the dynamic picture, the currently observed great complexity and diversity of the living organisms results from the process of their gradual evolution from simpler forms with natural selection as its main mechanism. ${ }^{17}$ The beginnings of evolutionary theology reach back to the fifties of

16 A. Einstein, Bertrand Russell a myślenie filozoficzne, in: Albert Einstein. Pisma filozoficzne, ed. S. Butryn, trans. from English K. Napiórkowski, De Agostini Polska - Ediciones Altaya Polska, Warszawa 2001, 255.

17 E.g. F.J. Ayala, Dar Karola Darwina dla nauki i religii, transl. from English P. Dawidowicz, Wydawnictwo Uniwersytetu Warszawskiego, Warszawa 2009. 
the previous century to the works of Teilhard de Chardin ${ }^{18}$ and Karl Rahner. ${ }^{19}$ The major contribution to its establishment and development, however, comes from the works of such renowned contemporary scholars as Arthur Peacocke, ${ }^{20}$ John Haught, ${ }^{21}$ Dennis Edwards, ${ }^{22}$ Francisco J. Ayala, ${ }^{23}$ and Michael Heller. ${ }^{24}$ Evolutionary theology is a highly interdisciplinary project operating at the nexus of theology, philosophy, natural sciences and humanities. By saying that theology is evolutionary, however, one by no means implies the relativization of the Divine truths. Rather, one points only to the shift of the conceptual basis of the theological expression from the pre-scientific static to the scientific dynamic picture of the world. ${ }^{25}$ Inasmuch as many interesting and promising results have already been obtained evolutionary theology still needs much refinement and consolidation in order to fully merit the designation of a paradigm, that is, a commonly shared system of beliefs on the nature of theology and the methodological means to attain progress in theological

18 P.T. de Chardin, The Phenomenon of Man, William Collins, London 1959.

19 K. Rahner, Christology Within an Evolutionary World, in: K. Rahner, Theological Investigations V, Helicon Press, Baltimore 1966, 157-192.

20 E.g. A. Peacocke, Theology for a Scientific Age, Fortress Press, Minneapolis, 1993.

21 J. Haught, Is Nature Enough?: Meaning and Truth in the Age of Science, Cambridge University Press, Cambridge 2006; J. Haught, God After Darwin: A Theology of Evolution, Westview Press, Boulder CO 2008; J. Haught, Making Sense of Evolution: Darwin, God and the Drama of Life, Westminster John Knox Press 2010; J. Haught, Resting on the Future: Catholic Theology for an Unfinished Universe, Bloomsbury, New York - London - Oxford - New Delhi - Sydney 2015; J. Haught, The New Cosmic Story: Inside Our Awakening Universe, Yale University Press, New Haven - London 2017.

22 E.g. D. Edwards, Bóg ewolucji: teologia trynitarna, trans. from English Ł. Kwiatek, Copernicus Center Press, Kraków 2016.

23 F.J. Ayala, Dar Karola Darwina dla nauki i religii, op. cit.

24 E.g. M. Heller, Sens życia i sens Wszechświata, Tarnów, Biblos 2002, 135-151.

25 E.g. J. Turek, Filozoficzno-światopoglądowe implikacje dynamicznego obrazu wszechświata, in: M. Heller, S. Budzik, S. Wszołek, Obrazy świata w teologii i w naukach przyrodniczych, op. cit., 25-145. 
knowledge. ${ }^{26}$ The incentive to engage evolutionary scenarios into theological thought has been clearly advocated by Vatican II in the following statement: "History itself speeds along on so rapid a course that an individual person can scarcely keep abreast of it. The destiny of the human community has become all of a piece, where once the various groups of men had a kind of private history of their own. Thus, the human race has passed from a rather static concept of reality to a more dynamic, evolutionary one. In consequence there has arisen a new series of problems, a series as numerous as can be, calling for efforts of analysis and synthesis." 27

\section{METHODOLOGICAL ISSUES}

The proper argument that evolutionary theology does indeed set a new chapter in the relations between science and theology will commence with several methodological remarks on the nature of this novel theological approach. Most generally, theology aims at the conceptual exposition of the content of revelation. Since it is always man who is the recipient of the Divine revelation, theology is conditioned by the relation between man and God, that is, the encounter of the human mind with the revealed content. ${ }^{28}$ This means that conceptual frameworks of purely natural origin must be used to provide a proper expression for such content and, thus, that an objective theological cognition is impossible. Consequently, theological expression can never escape the significant tension between the finite character of the conceptual framework and the infinity of God. In other words, concepts can never reach the Divine essence in a literal sense, but only

26 E.g. W.P. Grygiel, What is invariant? On the possibility and perspectives of the evolutionary theology, ,Studia Koszalińsko-Kołobrzeskie 25(2018), 83-101; D. Wąsek, W.P. Grygiel, Przyczynki do teologii ewolucyjnej, in: Powstanie człowieka w ujęciu interdyscyplinarnym, ed. T. Maziarka, Copernicus Center Press, Kraków 2019, 55-171.

27 Vaticanum II, Gaudium et spes, Art. 5.

28 Vaticanum II, Dei Verbum, Art. 11, 12. 
by means of metaphorical language. Each metaphor is equipped with a subjective component because their proper interpretation demands involvement on the part of the recipient. The literal reading of these forms of expression may lead to serious error and absurd inferences. ${ }^{29}$

This set of ideas was developed by two famous 20th-century theologians, Edmund Schillebeeckx and Karl Rahner. In one of his most important works on theological hermeneutics, Schillebeeckx proposed that the Divine revelation is never received as a nuda vox Dei. Rather, each expression of the revealed content is coded in such a way as to permit a concrete recipient living in concrete times to read the Divine message. ${ }^{30}$ Karl Rahner wrote that each dogma is like an amalgam uniting both variable and invariable elements: "The truths which from the dogmatic point of view are absolutely binding can be expressed and handed down by means of ideas (propagated de facto at a given period in time by means of models and accepted patterns of reasoning), conveyed inseparably with the with the basic doctrinal statement, and later on considered as having no binding power or even false." 31

The process of communicating what is objective, essential and invariable with the concomitant elimination of contextual assumptions amounts to the development of a dogma and takes place according to specific criteria. ${ }^{32}$ This point has been greatly captured by a contemporary American evolutionary theologian, John Haught, who states the following: "The deposit of the Catholic faith is not a smoothly rounded rock rolling down the corridors of time cushioned

29 E.g. D.B. Hart, Chrześcijańska rewolucja a złudzenie ateizmu, trans. from English A. Gomola, WAM, Kraków 2011.

30 E. Schillebeeckx, O katolickie zastosowanie hermeneutyki, trans. from German H. Bortnowska, Znak (1968)7-8(169-170), 978-981.

31 K. Rahner, Dogmen und Theologiegeschichte - Gestern und Morgen, Zeitschrift für katholische Theologie 99(1977)1, 6.

32 E.g. Z. Kijas, Rozwój dogmatu i jego kryteria, in: Teologia fundamentalna. Vol. V: Poznanie teologiczne, eds. T. Dzidek, Ł. Kamykowski, A. Napiórkowski, Wydawnictwo Naukowe PAT, Kraków 2006, $106 f$. 
from changing cultures and fluctuating intellectual environments. Doctrine can and must develop if it is to be the basis of an enlivening spirituality for different periods of time. In fact, theology has always been one of the ways in which living religions have struggled to survive." 33

It is now commonly maintained that any theological formulation depends on a specific picture of the world. According to Liana, the hermeneutical category of the picture of the world consists of two principal components: (1) "a certain complete set of convictions on the fundamental characteristics and the mode of the functioning of the Universe, man and cognition itself" and (2) "a certain intellectual background or a specific background knowledge of all possible cognitive behaviors of man with the theological and scientific cognition inclusive." 34 Also, there are two main ideas articulated in the hermeneutics of the image of the Universe. Firstly, all our beliefs including the religious, theological and scientific ones function in a broader context of cultural conditions. In short, they bear contextual character. Secondly, these conditions are subject to historical variability with its main element being the evolution of concepts used to form a mental representation of the objective reality. As mentioned above, religious beliefs engage elements of both religious and non-religious nature and the tools to regulate the non-religious component lie outside of the competence of religion. ${ }^{35}$ This greatly concerns the changing picture of the world because it directly depends on the scientific knowledge of the structure of the Universe. Since religious beliefs must necessarily reflect the truth or, more precisely, be in its closest possible proximity, the unceasing improvement of the

33 J. Haught, Resting on the Future, op. cit., 29.

34 Z. Liana, Teologia a naukowe obrazy świata, in: Wiara i nauka, ed. J. Mączka, Wydawnictwo Uniwersytetu Jagiellońskiego, Kraków 2010, 70-71.

35 E.g. M. Heller, Naukowy obraz świata a zadanie teologa, in: Obrazy świata w teologii i w naukach przyrodniczych, eds. M. Heller, S. Budzik, S. Wszołek, Biblos, Tarnów 1996, 13-27. 
picture of the world that they contain is of prime importance for their credibility. ${ }^{36}$ It has already been clearly indicated by St. Basil that the deepening of the knowledge of the Universe results in the constant enrichment of the conceptual basis of theology, whereby more fitting analogies can be developed to refract the Divine essence. ${ }^{37}$

\section{RESHAPING THE INTEGRATION}

As one now turns to the detailed justification of the synthesis of faith and reason as exemplified by evolutionary theology, it is fitting to return briefly to the synthesis accomplished by St. Thomas Aquinas as the proper background for further analysis. After all, this is the last major synthesis where faith and reason were harmoniously integrated in a worldview which brings both the natural and supernatural realms into a coherent unity. Barbour indicated three possible versions of the integration model: natural theology, theology of nature and systematic synthesis. It is quite obvious that the synthesis of Aquinas does justice to the first version, for he devoted considerable effort to show how one can argue for the existence of God and justify some basic characteristics of the Divine essence accessible to the inquiry of reason alone. ${ }^{38}$ The second version of integration, however, does not seem to apply as smoothly to the synthesis of Aquinas. Barbour points out that "in the theology of nature, the main sources of theology lie outside of science, but scientific theories may strongly affect the reformulation of certain doctrines, particularly the doctrine of creation and the human nature." 39 Although Aquinas does not operate with a contemporary notion of science, such reformulation

36 St. Augustine, De Genesi ad litteram I, 19-20.

37 St. Basil, De legendis libris Gentilium, 565 and 568.

38 For an exhaustive commentary of Aquinas' natural theology, see: N. Kretzmann, The Metaphysics of Theism: Aquinas' Natural Theology in Summa Contra Gentiles I, Oxford University Press, Oxford 1997.

39 I.G. Barbour, When Science Meets Religion, op. cit., 27-28. 
does indeed occur within the conceptual shift from Neoplatonism to Aristotelianism. Considering that these systems comprised much of the knowledge on the nature of the physical reality at the time, the theology of nature version may be applied to Aquinas' synthesis in an extended sense. The two cases mentioned by Barbour in the quote above provide an excellent example in this regard. As for the third version of integration proposed by Barbour, it is clearly refracted in the synthesis effected in Aquinas metaphysics that is based on the real distinction between esse et essentia. ${ }^{40}$ Understood in the Aristotelian sense of the ultimate principles of reality, this metaphysics implies the ontology of substances as the fundamental ontology underpinning all that exists.

The unifying power and conceptual clarity of the Thomistic metaphysics still sparks much interest among philosophers and theologians. However, it is rather the framework shift mentioned above that constitutes the "truly valuable" in Aquinas, whereby the transition to a new chapter concerning the relations between science and theology can proceed. Such shift was a purification because the metaphorical and symbolic language of Neoplatonism succumbed to the greater conceptual clarity and logical transparency of Aristotelianism. Interestingly enough, a very similar idea has been articulated in reference to the contemporary sciences by John Paul II in his letter to the Director of the Vatican Observatory, George Coyne, in which he stated that "science can purify religion from error and superstition; religion can purify science from idolatry and false absolutes." ${ }^{41}$ Although the conceptual shift achieved by Aquinas took place before the onset of the contemporary scientific method, it

40 For an incisive introduction to the metaphysics of esse, see: F. Wilhelmsen, Being and Knowing, Preserving Christian Publications, Albany, New York 1995, 47-80.

41 John Paul II, The Letter to the Reverend George V. Coyne, S.J., Director of the Vatican Observatory, in: J. Russell, W.R. Stoeger, G.V. Coyne, Physics, Philosophy and Theology: A Common Quest for Understanding, Vatican Observatory Foundation, Vatican 1988, M13. 
revealed some of the dynamics proper to the development of science accomplished with the use of this method. This in turn made the question of the fundamental ontology implied by the contemporary scientific theories a highly contentious issue. ${ }^{42}$ Considering that the theoretical objects postulated by science change with the theories, John Worrall has proposed that these concern the structures rather than the objects that span the fundamental ontology of reality. This philosophical stance is called structural realism..$^{43}$ It is currently believed that the structural character of reality is most properly reflected in the category theory. This highly abstract mathematical framework rests on the priority of relations (morphisms) with respect to objects and has been suggested to constitute a fundamental ontology referred to by Michał Heller as the category field ${ }^{44}$ This is the updated version of his older idea of the formal field or the field of rationality. ${ }^{45}$ Einstein suggested that the only feature that pertains to the mindindependent objective reality is its logical simplicity. ${ }^{46}$ Following the nature of the contemporary scientific method, however, there are no general a priori assumptions that can be made regarding the specificity of a hypothetical fundamental ontology for even the most abstract formalisms may eventually turn out either empirically or theoretically inadequate (or both) and be replaced with ones which imply ontologies remaining at present entirely unknown. Since the growth of the scientific knowledge leads to the marked generalization of the theoretical description with concomitant increase in their predictive accuracy, the theoretical grasp on the fabric of the Universe

42 E.g. A. Chakravartty, A Metaphysics for Scientific Realism, Cambridge University Press, Cambridge 2007.

43 J. Worrall, Structural realism: The best of both worlds?, Dialectica 43(1989)1-2, 99-124.

$44 \mathrm{M}$. Heller, The field of rationality and category theory, in: Mathematical Structures of the Universe, eds. M. Eckstein, M. Heller, S. Szybka, Copernicus Center Press, Kraków 2014, 441-457.

45 M. Heller, Uchwycić przemijanie, Wydawnictwo Znak, Kraków 1997, 236-238.

46 E.g. A. Einstein, On The Generalized Theory of Gravitation, Scientific American 182(1950)4, 13-17. 
is considered to move to representations of increasing accuracy. To put things in short, as postulated by Karl Popper science yields only probable knowledge meaning that one cannot justify any ontology established with the use of the scientific method as fundamental, that is, assuming the status of metaphysics in the Aristotelian sense of the ultimate principles of reality.

Why is it then that evolutionary theology sets up a new synthesis between science and theology? Unlike the Aristotelian-Thomistic account it does not engage a conceptual framework that claims the status of a fundamental ontology. Like all theories formulated by means of the scientific method, the theory of evolution is subject to revision upon the acquisition of new empirical data that may contradict its current claims. Putting the matter in the words of John Paul II, the theological doctrine expressed with the use of the evolutionary picture of the world will always be open to purification once a new and more accurate theory of the origin and development of life in the Universe becomes available. It follows from this that any theology based on the scientific picture of the world admits a constant deepening of the exposition of Divine truths as more generalized conceptual frameworks become available. ${ }^{47}$ Consequently, theology acquires a natural disposition for the reinterpretation of the doctrine. In addition to this, theology is automatically equipped to reject the God of the gaps argument by depriving it of its power. Since no ontology is final, no scientific statements can acquire an absolute character. Should this happen for whatever reason, either on the side of science or theology, their conflict becomes reality in an instant. In other words, the synthesis of science and theology as exemplified by evolutionary theology permanently does away with the possibility of one ever opposing or contradicting the other.

47 E.g., W.P. Grygiel, In what Sense Can the Scientifically Driven Theology Be Considered as a Continuation of the Doctrinal Tradition?, The Theological Research 6(2018), 31-52. 
Moreover, since the scientific picture of the world can never become a basis for a fundamental ontology, the claims of natural theology become markedly weaker. Such claims are additionally diminished by the belief of respected representatives of the scientific milieu that even advanced scientific theories, such as the general theory of relativity, unveil only a very small fragment of the vastness of the physical reality. According to Einstein, this turns a scientist into a believer: "His religious feeling takes the form of a rapturous amazement at the harmony of natural law, which reveals an intelligence of such superiority that, compared with it, all the systematic thinking and acting of human beings is an utterly insignificant reflection." 48

The weakening of the claims of natural theology results in the practical denial of the possibility of proving the existence of God and inferring some of His basic attributes in favor of natural inquiry being only capable of establishing its own limits. Such limits, however, raise the question of what makes this inquiry possible or, phrased differently, what its metaphysical a priority is. As Heller puts it succinctly: "God is what makes the question marks have their answers." 49

In regard to the second version of integration, namely that of the theology of nature, two points need to be made. First, evolutionary theology does call for an extensive doctrinal reinterpretation as foreseen by John Paul II in the aforementioned letter to the Director of the Vatican Observatory: "If the cosmologies of the ancient Near Eastern world could be purified and assimilated into the first chapters of Genesis, might not contemporary cosmology have something to offer to our reflections upon creation? Does an evolutionary

48 A. Einstein, The Religiousness of Science, in: A. Einstein, The World as I See It, Open Road Integrated Media, New York 2010, 37.

49 M. Heller, Usprawiedliwienie Wszechświata, Wydawnictwo Znak, Kraków 1995, 93. See also: W.P. Grygiel, Człowiek wobec nauki: przez transgresję ku transcendencji, in: Po człowieku? Między kryzysem a nadzieją, ed. M. Lipowicz, Wydawnictwo WAM, Kraków 2018, 289-312. 
perspective bring any light to bear upon theological anthropology, the meaning of the human person as the imago Dei, the problem of Christology - and even upon the development of doctrine itself? What, it any, are the eschatological implications of contemporary cosmology, especially in light of the vast future of our universe? Can theological method fruitfully appropriate insights from scientific methodology and the philosophy of science?"50

It lies beyond the scope of this paper to address all the reinterpretative issues in the Christian doctrine that become evident upon the assimilation of the evolutionary picture of the world. Their full spectrum can be gleaned from the works of John Haught and Dennis Edwards referred to above. What seems to attract the greatest attention is, however, the problem of the original sin and how this concept fades into mythology gradually exorcised from the theological discourse as the evolutionary picture of the world penetrates its realm. ${ }^{51}$

The proper articulation of the third version of the Barbourian category of integration in the context of the contemporary science, namely that of the synthesis, is best accomplished as one shifts from the theory of evolution to quantum mechanics. There are extensive studies on how meaningful contributions to theology can be made by taking into account the picture of the world pertinent to the quantum level. ${ }^{52}$ It turns out that quantum mechanics offers four independent formulations based on different mathematical structures that accord with the empirical evidence: ${ }^{53}$ the Hilbert spaces, the Feynman path

50 John Paul II, The Letter to the Director of the Vatican Observatory, op. cit., M11.

51 E.g. M. Majewski, Grzech pierworodny. Nowe modele lektury Księgi Rodzaju w teologii katolickiej w kontekście współczesnych nauk przyrodniczych, Ex Nihilo. Periodyk Młodych Religioznawców 17(2017), 1-31.

52 E.g., R.J. Russell, Quantum Physics in Philosophical and Theological Persepctive, in: R.J. Russell, W.R. Stoeger, G.V. Coyne (eds.), Physics, Philosophy and Theology: A Common Quest for Understanding, Vatican Observatory, Vatican City State 2000, 343-374.

53 M. Heller, Elementy mechaniki kwantowej dla filozofów, Biblos, Tarnów 2011, 140-147. 
integrals, $\mathrm{C}^{*}$-algebras and the statistical approach based on density matrices. According to Heller, such a situation is consistent with Platonic ontology, in which all these formulations are but parallel representations of an objective physical reality to which the human intellect has restricted access. In short, it cognizes this reality only from a certain perspective. At this point it is hard to resist a farreaching similarity of this mode of epistemic access to the physical reality with the nature of the theological discourse discussed above. Since this intriguing issue cannot be fully addressed within the scope of this article, it suffices to mention that the new synthesis of science and theology as exemplified by quantum mechanics provides a unique opportunity to support several valid formulations of the same theological doctrine. In other words, the synthesis allows for philosophical pluralism in theology and as such can be considered an extension and development of the Thomistic synthesis, which favors only one conceptual framework based on a certain reading of Aristotle.

\section{CONCLUSIONS}

In conclusion, it is worthwhile to observe yet another intriguing aspect of the integration between science and theology within the contemporary scientific method. However, since the method provides access only to the natural, or physical (contingent) order, it remains incapable of addressing the question of the existence of the Universe and its rational order. There exist layers of reality that transcend the capacity of the scientific method and, most importantly, they constitute the very reason why this method is altogether capable of providing rational answers. Theology claims to have epistemic access to such layers of reality, but it has no objective language to express its doctrine and must resort to conceptual frameworks provided by science and philosophy, which are products of the human intellect. There is no nuda vox Dei. Reflecting on these considerations, it turns 
out that the new synthesis of science and theology reveals the richness of their mutual interdependency while retaining the autonomy of the objects they study.

In addition to the substantial development of the synthesis of science and theology achieved in the context of the scientific method, two other factors deserve attention. Firstly, this synthesis deploys a unique position in the dialogue with contemporary scientific atheism, for no claims within science itself can ever be considered final and the doctrinal statements can be properly adjusted to reflect current scientific developments. This should also greatly aid the restoration of the credibility of theology as a legitimate area of rational inquiry. Secondly, since doctrinal formulations are but representations of the intellectually impenetrable Divine reality, the synthesis suggested can serve as a basis for a truly scientific spirituality in which scientific progress not only gradually unveils the mysteries of nature but also yields the tools to reach out to the Mystery of God Himself. One of the founders of quantum mechanics, Edwin Schrödinger, inquired which scientific achievements have best helped the religious outlook on the world. Heller answered as follows: "Personally, I think... that particular scientific achievements do not do this work best, but rather the scientific method itself." 54 This is precisely what the new synthesis of science and theology as exemplified by evolutionary theology is all about.

\section{BIBLIOGRAPHY}

Ayala F.J., Dar Darwina dla nauki i religii, trans. from English P. Dawidowicz, Wydawnictwo Uniwersytetu Warszawskiego, Warszawa 2009.

Barbour I.G., When Science Meets Religion, Harper One, New York 2000.

Behe M., Darwin's Black Box: The Biochemical Challenge to Evolution, The Free

Press, New York 1996.

54 M. Heller, Science and Transcendence, Studies in Science and Theology 4(1996), 3-12. 
Butrnyn S. (ed.), Albert Einstein. Pisma filozoficzne, trans. from English K. Napiórkowski, De Agostini Polska - Ediciones Altaya Polska, Warszawa 2001.

Chakravartty A., A Metaphysics for Scientific Realism, Cambridge University Press, Cambridge 2007.

Chardin P.T. de, The Phenomenon of Man, William Collins, London 1959.

Dawkins R., The God Delusion, Bantam Books, New York 2006.

Dembski W.A., The Design Inference: Eliminating Chance Through Small Probabilities, Cambridge University Press, Cambridge 1995.

Edwards D., The God of Evolution. A Trinitarian Theology, The Paulist Press, Minnesota 1999.

Einstein A., On The Generalized Theory of Gravitation, Scientific American 182(1950)4, 13-17.

Einstein A., The Religiousness of Science, in: A. Einstein, The World as I See It, Open Road Integrated Media, New York 2010, 33-43.

Grygiel W.P., Cztowiek wobec nauki: przez transgresję ku transcendencji, in: Pocztowieku? Między kryzysem a nadzieja, ed. M. Lipowicz, Wydawnictwo WAM, Kraków 2018, 289-312.

Grygiel W.P., In what Sense Can the Scientifically Driven Theology Be Considered as a Continuation of the Doctrinal Tradition?, The Theological Research 6(2018), 31-52.

Grygiel W.P., Konceptualne wyzwania nauk kognitywnych dla antropologii filozoficznej i teologicznej, in: Teologia fundamentalna wobec wspótczesnych wyzwań nauko cztowieku, ed. P. Artemiuk, Płocki Instytut Wydawniczy, Płock 2019, 120-143.

Grygiel W.P., What Is Invariant? On the Possibility and Perspectives of the Evolutionary Theology, Studia Koszalińsko-Kołobrzeskie 25(2018), 83-101.

Hart D.B., Chrześcijańska rewolucja a ztudzenie ateizmu, WAM, Kraków 2011.

Haught J., God After Darwin: A Theology of Evolution, Westview Press, Boulder 2008.

Haught J., Is Nature Enough?: Meaning and Truth in the Age of Science, Cambridge University Press, Cambridge 2006.

Haught J., Making Sense of Evolution: Darwin, God and the Drama of Life, Westminster John Knox Press 2010.

Haught J., Resting on the Future: Catholic Theology for an Unfinished Universe, Bloomsbury, New York - London - Oxford - New Delhi - Sydney 2015.

Haught J., The Nerw Cosmic Story: Inside Our Awakening Universe, Yale University Press, New Haven - London 2017.

Heller M., Elementy mechaniki kwantowej dla filozofów, Biblos, Tarnów 2011. 
Heller M., Naukowy obraz świata a zadanie teologa, in: Obrazy świata w teologii $i$ w naukach przyrodniczych, eds. M. Heller, S. Budzik, S. Wszołek, Biblos, Tarnów 1996, 13-27.

Heller M., Science and Transcendence, Studies in Science and Theology 4(1996), 3-12. Heller M., Sens życia i sens Wszecbświata, Tarnów, Biblos 2002.

Heller M., The field of rationality and category theory, in: Mathematical Structures of the Universe, eds. M. Eckstein, M. Heller, S. Szybka, Copernicus Center Press, Kraków 2014, 441-457.

Heller M., Uchwycić przemijanie, Wydawnictwo Znak, Kraków 1997.

Heller M., Usprawiedliwienie Wszechświata, Wydawnictwo Znak, Kraków 1995. John Paul II, Fides et Ratio, Vatican City State 1998.

John Paul II, The Letter to the Reverend George V. Coyne, S.J., Director of the Vatican Observatory, in: J. Russell, W.R. Stoeger, G.V. Coyne, Physics, Philosophy and Theology: A Common Quest for Understanding, Vatican Observatory Foundation, Vatican 1988.

Keane G.J., Creation Rediscovered: Evolution and The Importance of the Origins Debate, TAN Books and Publishers, Rockford 1999.

Kijas Z., Rozwój dogmatu ijegokryteria, in: Teologia fundamentalna. Vol. V: Poznanie teologiczne, eds. T. Dzidek, Ł. Kamykowski, A. Napiórkowski, Wydawnictwo Naukowe PAT, Kraków 2006.

Kretzmann N., The Metaphysics of Theism: Aquinas' Natural Theology in Summa Contra Gentiles I, Oxford University Press, Oxford 1997.

Lambert D., Sciences et théologie - Les figures d'un dialogue, Lessius, Bruxelles 1999. Liana Z., Teologia a naukowe obrazy świata, in: Wiara i nauka, ed. J. Mączka, Wydawnictwo Uniwersytetu Jagiellońskiego, Kraków 2010, 69-89.

Majewski M., Grzech pierworodny. Nowe modele lektury Ksiegi Rodzaju w teologii katolickiej w kontekście wspótczesnych nauk przyrodniczych, Ex Nihilo. Periodyk Młodych Religioznawców 17(2017), 1-31.

Mączka J., Średniowieczny konflikt nauki z teologia (potępienie z 1277 r.), in: M. Heller, Z. Liana, J. Mączka, W. Skoczny, Nauki przyrodnicze a teologia: konflikt i wspótistnienie, OBI - Biblos, Kraków - Tarnów 2001, 115-126.

Owens J., Cognition: An Epistemological Inquiry, Center for Thomistic Studies, Houston 1992.

Peacocke A., Theology for a Scientific Age: Being and Becoming - Natural, Divine and Human, Fortress Press, Minneapolis 1993.

Pedersen O., The Two Books: Historical Notes on Some Interactions Between Natural Science and Theology, Vatican Observatory Foundation, Vatican City 2007. 
Pieper J., Scholasticism: Personalities and Problems of Medieval Philosophy, St. Augustine Press, South Bend 2001.

Rahner K., Christology Within an Evolutionary World, in: K. Rahner, Theological Investigations V, Helicon Press, Baltimore 1966, 157-192.

Rahner K., Dogmen und Theologiegeschichte - Gestern und Morgen, Zeitschrift für katholische Theologie 99(1977)1, 1-24.

Russell R.J., Quantum Physics in Philosophical and Theological Persepctive, in: Physics, Philosophy and Theology: A Common Quest for Understanding, eds. R.J. Russell, W.R. Stoeger, G.V. Coyne, Vatican Observatory, Vatican City State 2000, 343-374.

Schillebeeckx E., O katolickie zastosowanie hermeneutyki. Tożsamośc wiary w toku jej reinterpretacji, trans. from Germany H. Bortnowska, Znak (1968)7-8(169170), 978-981.

St. Augustine, De Genesi ad litteram I, ed. J. Zecha, Bibliopola Academiae Litterarum Caesareae, Vienna 1894.

St. Basil, De legendis gentilium libris, ed. F. Boulenger, Paris 1935

St. Thomas Aquinas, Summa Contra Gentiles I (Latin-English Opera Omnia), ed. The Aquinas Institute, Emmaus Academic 2019

Thomas Aquinas, Faith, Reason and Theology. Questions I-IV of his Commentary on the ,De Trinitate” of Boethius, Pontifical Institute of Medieval Studies, Toronto 1987.

Turek J., Filozoficzno-światopoglądowe implikacje dynamicznego obrazu wszechświata, in: Obrazy świata w teologii i w naukach przyrodniczych, eds. M. Heller, S. Budzik, S. Wszołek, Biblos, Tarnów 1996, 25-145.

Vaticanum II, Dei Verbum, in: Vatican Council II, The Conciliar and Post Conciliar Documents, ed. A. Flannery, Costello Publishing Company, Northport, New York 1980, 750-765.

Vaticanum II, Gaudium et spes, in: Vatican Council II, The Conciliar and Post Conciliar Documents, ed. A. Flannery, Costello Publishing Company, Northport, New York 1980, 903-1014.

Wąsek D., Grygiel W.P., Przyczynki do teologii ewolucyjnej, in: Powstanie cztowieka w ujęciu interdyscyplinarnym, ed. T. Maziarka, Copernicus Center Press, Kraków 2019, 55-171.

Wilhelmsen F., Being and Knowing, Preserving Christian Publications, Albany, New York 1995.

Worall J., Structural realism: The best of both worlds?, Dialectica 43(1989)1-2, 99-124. 
Wojciech Grygiel

Uniwersytet Papieski Jana Pawła II w Krakowie

(The Pontifical University of John Paul II in Kraków, Department of Philosophy, Poland)

Centrum Kopernika Badań Interdyscyplinarnych Uniwersytetu Jagiellońskiego

(The Copernicus Center for the Interdisciplinary Studies, Kraków, Poland)

ORCID: https://orcid.org/0000-0003-2599-0410

wojciech.grygiel@upjp2.edu.pl

DOI: $10.21697 /$ spch.2020.56.3.05 